\title{
Low Birth, Prematurity, and Pre-Eclampsia as Risk Factors of Neonatal Asphyxia
}

\author{
Remita Yuli Kusumaningrum', Bhisma Murti'), Hanung Prasetya ${ }^{2)}$ \\ 1) Masters Program in Public Health, Universitas Sebelas Maret \\ ${ }^{2)}$ School of Health Polytechnics Surakarta
}

\begin{abstract}
Background: Asphyxia neonatorum is the condition of an infant who does not breathe spontaneously and regularly immediately after birth. This condition is accompanied by hypoxia, hypercapnia, and ends with acidosis. Long-standing asphyxia can cause brain damage and death. This study aimed to investigate risk factors of asphyxia in Nganjuk Hospital, East Java.

Subjects and Method: This was an analytic observational study with a case control design. The study was conducted in Nganjuk Hospital, East Java, in July 2018. A total sample of 150 neonates was selected by fixed disease sampling, consisting of 50 neonates with asphyxia and 100 neonates without asphyxia. The dependent variable was asphyxia. The independent variables were low birth weight, preterm birth, and pre eclampsia. The data were obtained from medical record and analyzed by a multiple logistic regression.

Results: The risk of asphyxia increased with low birth weight $(\mathrm{OR}=2.58$; $95 \% \mathrm{CI}=3.80$ to 46.15 ; $\mathrm{p}<0.001)$, premature birth $(\mathrm{OR}=1.27 ; 95 \% \mathrm{CI}=1.23$ to $10.25 ; \mathrm{p}=0.019)$, and pre-eclampsia $(\mathrm{OR}=$ $3.74 ; 95 \% \mathrm{CI}=12.54$ to $141.05 ; \mathrm{p}<0.001)$.

Conclusions: The risk of asphyxia increases with low birth weight, premature birth, and preeclampsia.
\end{abstract}

Keywords: asphyxia, neonates, low birth weight, premature, preeclampsia

\section{Correspondence:}

Remita Yuli Kusumaningrum. Masters Program in Public Health, Universitas Sebelas Maret. Jl. Ir. Sutami 36A, Surakarta 57126, Central Java. Email: renita.yuli@gmail.com.

Mobile: +6281231871222 .

\section{BACKGROUND}

Asphyxia is spontaneous and regular respiratory failure at birth or shortly after birth (Prambudi, 2013). The transition from the life of the intrauterine fetus to the extrauterine infant's life shows change. Failure to decrease pulmonary vascular resistance causes persistent pulmonary hypertension in newborns, inadequate pulmonary blood flow and relative hypoxemia. Inadequate lung expansion causes respiratory failure (Kosim, 2014).

Infant mortality can be caused by asphyxia. The infant mortality rate (IMR) in ASEAN ranks second highest at 142 per 1000 after Africa. Indonesia is a country with a higher infant mortality rate which is in the $5^{\text {th }}$ place in ASEAN (WHO, 2015).

The IMR issued by the Central Bureau of Statistics in East Java Province in 2012 was 28.31 per 1 ,00o live births. $27.38 \%$ of neonatal deaths are caused by asphyxia (East Java Health Office, 2012). Throughout 2014 in Nganjuk District, the neonatal mortality rate was 131 cases or 8 per 1,000 live births with 25,146 births. The cause of neonatal death (0-28 days) in Nganjuk Regency is largely due to LBW, asphyxia, congenital abnormalities and infections. (Nganjuk Health Office, 2014). The incidence of asphyxia in Nganjuk Regional Hospital in 2017 was 162 cases (4.24\%) out 
Journal of Maternal and Child Health (2019), 4(1): 49-54

https://doi.org/10.26911/thejmch.2019.04.01.07

of 1,011 infants born (Nganjuk Health Office, 2017).

Premature infants are at risk of developing asphyxial complications because of the incomplete formation of vital organs and the lack of ability of the infant's respiratory organs to carry out their functions. Pre-eclampsia is one of the predisposing factors for placental insufficiency that can cause ante and intrapartum hypoxia, fetal growth is inhibited and preterm labor (Muslihatun, 2010).

Complications can occur due to asphyxia include hypoxia, hypercapnia and metabolic acidosis (Muslihatun, 2010). Neonatal asphyxia causes morbidity and mortality. Mortality incidence is $20 \%$ and neurological disability is estimated at around 25\% (Antonucci et al, 2014). In addition, asphyxia can also cause physical abnormalities and mental development, such as cerebral palsy, mental retardation, epilepsy, and learning disabilities (Mohan et al, 2013).

Childbirth assistance must be carried out by health personnel who have the knowledge and skills of Asphyxia Management in newborns is an effort to reduce the incidence of asphyxia. As a preventive effort, health personnnel provide motivation and education on the importance of nutrition intake, detect and avoid the risk of neonatal asphyxia for pregnant women to reduce the incidence of neonatal asphyxia. Especially for pregnant women who experience pregnancy complications, it is necessary to prepare a labor process that minimizes the risk of neonatal asphyxia (Rukiyah, 2012). Gerdaristi (Movement for High Risk Assistance) in pregnant women is one of the efforts of Nganjuk District in reducing the incidence of neonatal asphyxia (Health Office, 2017).

The purpose of this study was to explain the effect of low birth weight, premature, pre-eclampsia, and neonatal asphyxia in Nganjuk Hospital, East Java.

\section{SUBJECTS AND METHOD \\ 1. Study Design \\ This was an analytic observational study with a case control design. The study was carried out at Nganjuk Hospital, East Java, in July 2018.}

\section{Study Population and Samples}

The study population was all infants in the neonatal room, Nganjuk Hospital, from January to December 2017. A total sample of 150 infants was selected by fixed disease sampling, including 50 infants with asphyxia and 100 neonates without asphyxia.

\section{Study Variables}

The dependent variable was neonatal asphyxia. The independent variables were low birth weight, premature, and pre eclampsia

\section{Operational Definition of Variable}

Asphyxia neonatorum was defined as a condition of babies born having difficulty breathing with APGAR scores less than 7 in the first 5 minutes. The measurement results were divided into two: a) asphyxia is if the APGAR value is $\leq 6$ in the first 5 minutes with the code " 1 " and b) not asphyxia is if the value is $>6$ in the first 5 minutes with the code "o". The data were taken from medical records. The measurement scale was continuous.

Low birth weight (LBW) was defined as an infant born with a birth weight less than 2500 grams. The data were taken from medical record. The measurement scale was continuous, but for the purpose of data analysis, it was transformed into dichotomous, coded o for normal birthweight and 1 for LBW.

Premature was defined as an infant born $<37$ weeks' gestation. The data were taken from medical record. The measurement scale was continuous, but for the purpose of data analysis, it was transformed into 
dichotomous, coded o for premature and 1 for normal.

Pre eclampsia was defined as a condition when infants born to mother with pre-eclampsia or eclampsia. The data were taken from medical record. The measurement scale was categorical, coded o for did not have pre eclampsia and 1 for pre eclampsia.

\section{Data Analysis}

The data analysis included univariate, bivariate, and multivariate analysis. Multivariate analysis was done by a multiple logistic regression analysis.

\section{Research Ethics}

The research ethics included informed consent, anonymity, confidentiality, and ethical clearance.

\section{RESULTS \\ 1. Univariate Analysis \\ The results of univariate analysis were shown in table 1 . Table 1 showed that infants with low birth weight were 70 (46.7\%). The number of infants with preterm birth was 53 (35.3\%). The number of pre eclampsia was 56 (37.3\%).}

\section{Bivariate Analysis}

The data were analyzed by Chi-square to observe the relationship between LBW, preterm, and pre eclampsia with neonatal asphyxia. The results of bivariate analysis can be seen in table 2 .

Table 1. The Results of Univariate Analysis

\begin{tabular}{lcc}
\hline \multicolumn{1}{c}{ Variable } & n & \% \\
\hline Asphyxia & & \\
Yes & 50 & 33.3 \\
No & 100 & 66.7 \\
Low Birth Weight & & \\
LBW & 70 & 46.7 \\
Normal birthweight & 80 & 53.3 \\
Prematurity & & \\
Premature & 53 & 35.3 \\
Not Premature & 97 & 64.7 \\
Pre-eclampsia & & \\
Pre-eclampsia & 56 & 37.3 \\
Non Pre-eclampsia & 94 & 62.7 \\
\hline
\end{tabular}

\section{Multivariate Analysis}

The results of multivariate analysis by using multiple logistic regression can be seen in Table 3. Table 3 showed that there was a positive relationship between LBW, premature, and pre eclampsia on the incidence of neonatal asphyxia. Table 3 showed that the risk of neonatal asphyxia was increased with $\mathrm{LBW}(\mathrm{OR}=2,58 ; 95 \% \mathrm{CI}=3.80$ to 46.15; $\mathrm{p}<0.001)$, premature birth $(\mathrm{OR}=$ 1.27; $95 \% \mathrm{CI}=1.23$ to $10.25 ; \mathrm{p}=0.019)$, pre eclampsia $(\mathrm{OR}=3.74 ; 95 \% \mathrm{CI}=12.54$ to 141.05; $\mathrm{p}<0.001)$.

Table 2. The results of bivariate analysis on the risk factors of neonatal asphyxia

\begin{tabular}{|c|c|c|c|c|c|c|c|c|c|c|}
\hline \multirow{4}{*}{$\begin{array}{l}\text { Independent } \\
\text { Variables }\end{array}$} & \multicolumn{4}{|c|}{ Asphyxia } & \multirow{3}{*}{\multicolumn{2}{|c|}{ Total }} & \multirow{4}{*}{$\mathbf{O R}$} & \multirow{2}{*}{\multicolumn{2}{|c|}{$95 \% \mathrm{CI}$}} & \multirow{4}{*}{$\mathbf{p}$} \\
\hline & \multirow{2}{*}{\multicolumn{2}{|c|}{$\begin{array}{c}\text { Yes } \\
(n=50)\end{array}$}} & \multirow{2}{*}{\multicolumn{2}{|c|}{$\begin{array}{c}\text { No } \\
(n=100)\end{array}$}} & & & & & & \\
\hline & & & & & & & & Lower & Upper & \\
\hline & $\mathbf{n}$ & $\%$ & $\mathbf{n}$ & $\%$ & $\mathbf{n}$ & $\%$ & & Limit & Limit & \\
\hline \multicolumn{11}{|l|}{ LBW } \\
\hline No & 15 & 18.8 & 65 & 81.2 & 80 & 100 & 4.33 & 2.09 & 9.00 & $<0.001$ \\
\hline Yes & 35 & 50 & 35 & 50 & 70 & 100 & & & & \\
\hline \multicolumn{11}{|l|}{$\begin{array}{l}\text { Premature } \\
\text { birth }\end{array}$} \\
\hline No & 24 & 24.7 & 73 & $75 \cdot 3$ & 97 & 100 & 2.93 & 1.44 & 5.95 & 0.002 \\
\hline Yes & 26 & 49.1 & 27 & 50.9 & 53 & 100 & & & & \\
\hline \multicolumn{11}{|l|}{$\begin{array}{l}\text { Pre } \\
\text { eclampsia }\end{array}$} \\
\hline No & 9 & 9.6 & 85 & 90.4 & 94 & 100 & 25.82 & 10.43 & 63.91 & $<0.001$ \\
\hline Yes & 41 & 26.8 & 15 & 73.2 & 56 & 100 & & & & \\
\hline
\end{tabular}


Journal of Maternal and Child Health (2019), 4(1): 49-54

https://doi.org/10.26911/thejmch.2019.04.01.07

Table 3. The results of a multiple logistic regression analysis on the risk factors of neonatal asphyxia

\begin{tabular}{lcccc}
\hline \multirow{2}{*}{ Independent Variables } & \multirow{2}{*}{ OR } & \multicolumn{2}{c}{ 95\% CI } & \multirow{2}{*}{ p } \\
\cline { 3 - 4 } & & Lower Limit & Upper Limit & \\
\hline LBW & 2.58 & 3.80 & 46.15 & $<0.001$ \\
Prematurity & 1.27 & 1.23 & 10.25 & 0.019 \\
Pre eclampsia & 3.74 & 12.54 & 141.05 & $<0.001$ \\
\hline
\end{tabular}

\section{DISCUSSIONS \\ 1. The Effect of LBW on Neonatal Asphyxia}

The result of analysis showed that there was an effect of LBW on the incidence of neonatal asphyxia which was statistically significant. Babies born with LBW would increase the risk of neonatal asphyxia than babies who did not have LBW (OR= 2.58; $95 \% \mathrm{CI}=3.80$ to $46.15 ; \mathrm{p}<0.001)$. The result of this study was in line with a study by Purwaningsih et al. (2018) which stated that LBW increased the risk of neonatal asphyxia by 4.45 times.

Proverawati and Atika (2010) stated that infants who have low birth weight (LBW) were more likely to have problems with the body system, due to unstable body conditions. One of the impacts of LBW was asphyxia in infants that can lead to short and long-term impact on the health of the infants. A study done by Momeni et al. (2017) stated that preterm labor has the risk of LBW by 22.6 times. LBW increased the risk of neonatal asphyxia.

This study was in line with Aslam et al. (2014) and Jebessa et al. (2018) which stated that LBW has the risk of neonatal asphyxia. Babies born with LBW have few alveoli and surfactants that were included in the alveoli. The surfactant function reduced the surface pressure of the lungs and helped to stabilize the alveolar wall so that there was no collapse at the end of breathing (Maryunani, 2009).

\section{The Effect of Prematurity on Neonatal Asphyxia}

The result of analysis showed that there was an effect of prematurity on the incidence of neonatal asphyxia which was statistically significant. Babies born prematurely were more likely to have asphyxia than nonpreterm infants $(\mathrm{OR}=1.27 ; 95 \% \mathrm{CI}=1.23$ to $10.25 ; \mathrm{p}=0.019)$. The result of this study was in line with the research conducted by Aminah and Wahyu (2016) which stated that prematurity increased the risk of neonatal asphyxia by 11.97 times.

Manuaba (2008) stated that premature babies were one of the causes of asphyxia. According to Indrayani (2013), asphyxia occured in premature infants due to lack of ability of the infant's respiratory organs in doing their functions.

This study was in line with Purwaningsih et al. (2018) who stated that prematurity increased the risk of asphyxia by 4.83 times. The result of a study by Utomo (2014) stated that premature has an effect on the incidence of asphyxia. Premature babies have immature lungs so that their breathing has not gone well. A study done by Momeni et al. (2017) stated that premature labor increased the risk of neonatal asphyxia.

\section{The Effect of Pre Eclampsia on Neonatal Asphyxia}

The result of analysis showed that there was an effect of pre eclampsia on the incidence of neonatal asphyxia which was statistically significant. Pre eclampsia would increase the risk of asphyxia than non pre eclampsia 
$(\mathrm{OR}=3.74 ; 95 \% \quad \mathrm{CI}=12.54$ to 141.05 ; $\mathrm{p}<0.001)$. The result of this study was in line with a study by Rachmawati and Ningsih (2015) which stated that there was a relationship between bad obstetric history and the incidence of asphyxia.

Mothers who experienced pre eclampsia tend to give birth to asphyxial babies. Endothelial dysfunction would lead to balance disorders on the levels of vasoconstrictor hormones and vasodilators (Cunningham, 2016).

Vascular vasoconstriction resulted in a lack of blood supply to the placenta which lead to fetal hypoxia. A further consequence of fetal hypoxia was a disruption of gas exchange between oxygen and carbon dioxide so that neonatal asphyxia occured (Winkjosastro, 2007).

The result of this study was in line with a study by Indah and Apriliana (2016) which stated that pre eclampsia which was characterized by high blood pressure caused a decrease in blood delivery to the placenta. Reducing the oxygen and food supply for babies can lead to neonatal asphyxia. A study by Jebessa et al. (2018) stated that bad obstetric history has a risk of increasing the incidence of neonatal asphyxia by 3.76 times than a good obstetric history.

\section{REFERENCES}

Aminah, Wahyu MS (2016). Hubungan Bayi Prematur dengan Kejadian Asfiksia Neonatorum. Jurnal Obstetrika Scientia. 4 (2)

Antonucci R, Porcella A, Pilloni MD (2014). Perinatal Asphyxia In The Term Newborn, Journal of Pediatric and Neonatal Individualized Medicine. 3(2): e030269. https://doi:10.7363/ 030269.
Aslam HM, Saleem S, Afzal R, Iqbal U, Saleem SM, Shaikh MWK, Shahid N (2014). Risk Factors of Birth As-phyxia, Italian. Journal of Pediatrics. https://bdoi.org/10.1186/s13052-014-0094-2

Cunningham FG (2016). Obstetri Williams. Jakarta: EGC

Dinkes (2012) Provinsi Jawa Timur (2012). Profil Kesehatan Provinsi Jawa Timur Tahun 2012. Dinas Kesehatan Jawa Timur

Dinas Kesehatan Kabupaten Nganjuk (2014). Profil Dinas Kesehatan Daerah Kab Nganjuk Tahun 2016

Ekwochi U, Asinobi NI, Osuorah CDI, Ndu $\mathrm{IK}$, Ifediora $\mathrm{C}$, Amadi $\mathrm{OF}$, Iheji $\mathrm{CC}$, Orjioke CJG, Okenwa WO and Okeke BI. (2017). Incidence and Predictors of Mortality Among Newborns With Perinatal Asphyxia: A 4-Year Prospective Study of Newborns Delivered in Health Care Facilities in Enugu, South-East Nigeria. Clinical Medicine Insights: Pediatrics, Gynecol. 118(3): 561-8. Doi: 10.1177/1179556517746646.

Ilah BG, Aminu MS, Musa A, Adelakun MB, Adeniji AO, Kolawole T (2015). Prevalence and Risk Factors for Perinatal Asphyxia as Seen at a Specialist Hospital in Gusau, Nigeria. Sub-Saharan Afr J Med. 2:64-9. Doi: 10.4103/2384-5147.157421

Indah SN, Apriliana E (2016). Hubungan antara Preeklamsia dalam Kehamilan dengan Kejadian Asfiksia pada Bayi Baru Lahir. Jurnal Majority. 5(5).

Jebessa Wayessa Z, Belachew T, Joseph J (2018). Birth asphyxia and associated factors among newborns delivered in Jimma zone public hospitals, Southwest Ethiopia: A cross - sectional study. Journal of Midwifery and 
Reproductive. Health. 6(2): 12891295. doi:10.22038/JMRH.2018.10483.

Kosim MS (2014). Buku Ajar Neonatologi. Jakarta: IDAI

Manuaba IBG (2008). Gawat Darurat Obstetri Ginekologi \& Obstetri Ginekologi Sosial Untuk Profesi Bidan. Jakarta: EGC

Maryunani A (2009). Asuhan Kegawatan Dan Penyulit Pada Neonatus. Jakarta: Trans Info Medika

Mohan K, Mishra PC, Singh DK. (2013). Cli-nical Profile of Birth Asphyxia In Newborn, International Journal of Science \& Technology. 3(1). ISSN (online): $250-141 \mathrm{X}$

Momeni M, Danaei M, Kermani AJ, Bakhshandeh M, Foroodnia S, Mahmoudabadi Z, Amirzadeh R, Safizadeh H. (2017). Prevalence and Risk Factors of Low Birth Weight in the Southeast of Iran. International Journal of Preventive Medicine. doi:10.4103/ijpvm.IJPVM_112_16.

Muslihatun. (2010). Asuhan Neonatus, Bayi Dan Balita. Yogyakarta: Fitramaya

Prambudi R (2013). Neonatologi Praktis: Prosedur Tindakan Neonatus. Ban- dar. Lampung: Anugrah Utama Raharja

Rachmawati L, Ningsih MP (2015). FaktorFaktor yang Berhubungan dengan Kejadian Asfiksia pada Bayi Baru Lahir Di Ruang Medical Record RSUD Pariaman. Jurnal Ilmiah Kebidanan. 7 (1): 29-40

Proverawati A (2010). Berat Badan Lahir Rendah. Yogyakarta: Nuha Medika

Purwaningsih Y, Dewi YLR, Indarto D, Murti B (2018). Factors Associated with Newborn Asphyxia at Dr. Harjono Hospital, Ponorogo, East Java. Journal of Maternal and Child Health. 3(4): 287-293. https://doi.org/10.26911/thejmch.2018.03.04.06

Rukiyah. (2010). Asuhan Neonatus Bayi Dan Anak Balita. Jakarta : Trans Info Medika

Wiknjosastro H (2007). Ilmu Kebidanan. Edisi Ke-4 Cetakan Ke-2. Jakarta: Yayasan Bina. Jakarta: EGC 